\title{
Dietary soy isoflavone intake in older Japanese American women
}

\author{
Madeline Murguia Rice ${ }^{1,2,3, *}$, Andrea Z LaCroix ${ }^{1,4}$, Johanna W Lampe ${ }^{1,4}$, Gerald van \\ Belle $^{5}$, Mark Kestin ${ }^{1,4,6}$, Megumi Sumitani ${ }^{3}$, Amy Borenstein Graves ${ }^{7}$ and Eric B Larson ${ }^{3}$ \\ 'Department of Epidemiology, University of Washington, Seattle, WA 98195, USA: ${ }^{2}$ Present address: University of \\ Washington Kame Project, Pacific Medical Center, Box 358261, 1200 12th Avenue S, Quarters 10, Seattle, WA \\ 98144, USA: ${ }^{3}$ Department of Medicine, University of Washington, Seattle, WA 98195, USA: ${ }^{4}$ Fred Hutchinson \\ Cancer Research Center, Seattle, WA 98109, USA: ${ }^{5}$ Department of Environmental Health, University of \\ Washington, Seattle, WA 98195, USA: ${ }^{6}$ Department of Nutrition, Bastyr University, Kenmore, WA 98011 , USA: \\ ${ }^{7}$ Department of Epidemiology and Biostatistics, University of South Florida, Tampa, FL 33612, USA
}

Submitted 10 September 2000: Accepted 16 February 2001

\begin{abstract}
Objective: In a sample of older Japanese American women, we aimed to: (1) describe the most commonly consumed soy foods, (2) estimate dietary soy isoflavone intake, (3) describe characteristics associated with dietary soy isoflavone intake, and (4) compare our estimates with previously published estimates in other Japanese samples.

Design: A 14-item soy food-frequency questionnaire was administered to older Japanese American women and responses were converted to quantitative estimates of soy isoflavones (genistein plus daidzein). Multiple regression was used to examine characteristics associated with dietary soy isoflavone intake, including self-reported lifestyle and cultural factors and dietary intake of various foods ascertained from a semi-quantitative food-frequency questionnaire. To compare our estimates with other samples, a review of the literature was conducted.

Setting/subjects: Data are from 274 women aged $65+$ years, recruited from a longitudinal cohort study of Japanese Americans in King County, Washington State. Results: The soy foods most commonly consumed were tofu (soybean curd), miso (fermented soybean paste) and aburaage (fried thin soybean curd). The mean intake of dietary soy isoflavones was 10.2 (standard deviation (SD), 12.4) $\mathrm{mg}$ day $^{-1}$, approximately a quarter to a half that of previously published estimates in Japanese samples. Dietary soy isoflavone intake was positively associated with speaking Japanese, the consumption of traditional Japanese dishes (kamaboko, manju and mochi), low-fat/non-fat milk and yellow/red vegetables, vitamin E supplement use, and walking several blocks each day. Dietary soy isoflavone intake was negatively associated with the consumption of butter.

Conclusions: The estimated dietary soy isoflavone intake in Japanese American women living in King County, Washington State was about a quarter to a half that of women living in Japan. Dietary soy isoflavone intake was associated with speaking Japanese and healthy lifestyle and dietary habits.
\end{abstract}

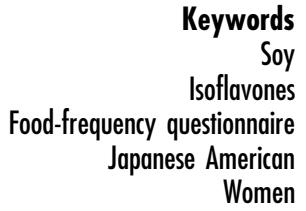

Women
The potential health effects of isoflavones have recently received considerable attention. Isoflavones are a class of phyto-oestrogens that are structurally similar to oestrogen, compete with oestradiol for binding sites, and stimulate the transcriptional activity of oestrogen receptors $^{1,2}$. Early examination into the potential health benefits of soy isoflavones was based on observed differences between Eastern and Western countries in the prevalence of cardiovascular disease, cancer and menopausal symptoms. Differences in the consumption of soy-derived food products, which are especially abundant in isoflavones, were indicted as a possible explanation $^{3-5}$. Researchers are currently examining associations between dietary soy isoflavone intake and various health outcomes via observational and intervention studies.

The dietary intake of soy isoflavones has been estimated in several Asian and Caucasian sampled populations $^{6-13}$; however, many of these studies relied on small sample sizes $(n<100)$. Further information on 
dietary soy isoflavone intake in various populations is needed. In addition, information is needed regarding the characteristics associated with dietary soy isoflavone intake that may confound or modify associations between soy and health outcomes.

The purpose of this study was to estimate the dietary intake of soy isoflavones in a sample of 274 older Japanese American women living in the Seattle area of Washington State. We also describe which soy foods were the most commonly consumed, and the lifestyle, cultural and dietary correlates of dietary soy isoflavone intake. Lastly, we compare our estimates with estimates from other Japanese and American samples.

\section{Methods}

\section{Study population}

Subjects included in the present study were recruited from a cohort of older Japanese American men and women living in the Seattle area of Washington State (the Kame Project). The Kame Project is a longitudinal, population-based cohort study of ageing and memory in Japanese Americans aged 65 years and older living in King County, $\mathrm{WA}^{14}$. The Kame Project identified individuals from King County telephone directories, Medicarerecipient lists, Japanese American organisational lists and by word-of-mouth, and enrolled 1985 men and women between May 1992 and September 1994.

Recruitment of study participants and eligibility criteria Letters of invitation for the present study were sent to a randomly selected sample of women participating in the Kame Project. Women also were informed of the present study through newsletters mailed quarterly to Kame Project participants and by word-of-mouth. To be eligible for the present study, women had to meet the same eligibility criteria as the Kame Project, including being aged 65 years or older, of at least 50\% Japanese ancestry, and living in King County, Washington State. In addition, women had to be ambulatory and able to self-report dietary and risk factor information. The University of Washington's Human Subjects Review Committee approved this study and written informed consent was obtained from all participants.

\section{Dietary soy assessment}

The Nikkei Soy Food Frequency Questionnaire (NSFFQ) The NSFFQ was designed to ascertain the usual frequency and serving size of soy foods consumed during the past year. To determine which soy foods should be included in the NSFFQ, a focus group was held among two of the investigators and seven women representing the Japanese American community of King County, WA (two Japanborn and five United-States-born; aged approximately 40 to 70 years). During this focus group discussion, a list of common soy foods available in the United States was discussed. Several foods uncommon to this population were deleted and other soy foods were added. In addition, several American and Japanese cookbooks were examined to determine if other soy foods may have been missed. A comprehensive list of soy foods was then compiled and agreed upon by consensus of the group. The NSFFQ included 14 soy foods: tofu, miso, aburaage, tofumame, natto, funyu, soybean condiment, edamame, atsuage, okara, soy milk, soy nuts, ganmodoki and koyadofu. Descriptions of these foods are found in Table 1. Most of the soy foods included in the NSFFQ were traditional Japanese foods, because it was determined that this population rarely consumed westernised soy foods.

A qualified bilingual translator translated the NSFFQ into Japanese. To ensure standardisation between the English and Japanese versions, the Japanese version was translated back into English by a different qualified translator. Any discrepancies were then corrected. The NSFFQ was administered in-person by a trained bilingual interviewer, in English or Japanese, depending on the participants' preference. For each soy food, a photograph and description was shown and participants were asked how often they ate the food during the past year. Participants were then asked about their usual serving size. Because there were no other sources available regarding the usual frequencies and serving sizes for these soy foods in this population, the NSFFQ was designed with open-ended questions. In addition, openended questions prevented respondents from merely choosing mid-range frequencies or serving sizes. Participants also were asked if they consumed any soy foods not mentioned in the NSFFQ. Other soy foods recalled by six or more participants included kinako, soy sprouts and soy burgers. Other soy foods recalled by only one participant included soy strips, tofu pie and soy dogs. These foods are described in Table 1.

Estimating the isoflavone (genistein and daidzein) content of soy foods

To estimate $\mathrm{mg}$ of dietary soy isoflavone intake, all responses were first converted to grams of each particular soy food and then multiplied by the amount of genistein and daidzein per gram of that food. Recently, the United States Department of Agriculture (USDA) and Iowa State University collaborated in the development of a database summarising the published and unpublished contents of daidzein and genistein in soy foods ${ }^{15}$. When available, mean values from this source were used. For foods not included in the USDA-Iowa State database, median isoflavone values were used, based upon an earlier extensive review of the literature by Reinli and Block ${ }^{16}$. The genistein and daidzein content of the soy foods in the above references were summary values for the conjugated plus unconjugated isoflavone forms, which 
Table 1 Description of soy foods included in the Nikkei Soy Food Frequency Questionnaire

\begin{tabular}{|c|c|}
\hline Soy food & Description \\
\hline $\begin{array}{l}\text { Soy foods included in t } \\
\text { Tofu } \\
\text { Miso } \\
\text { Aburaage } \\
\text { Tofumame } \\
\text { Natto } \\
\text { Funyu } \\
\text { Soybean condiment } \\
\text { Edamame } \\
\text { Atsuage } \\
\text { Okara } \\
\text { Soy milk } \\
\text { Soy nuts } \\
\text { Ganmodoki } \\
\text { Koyadofu }\end{array}$ & $\begin{array}{l}\text { Nikkei Soy Food Frequency Questionnaire } \\
\text { Soybean curd } \\
\text { Fermented soybean paste } \\
\text { Fried thin soybean curd } \\
\text { Dried soybeans } \\
\text { Fermented soybeans } \\
\text { Fermented soybean curd } \\
\text { Soybean paste, usually fermented } \\
\text { Fresh/frozen boiled soybeans (immature green soybeans) } \\
\text { Fried thick soybean curd } \\
\text { Insoluble soybean residue from soy milk production } \\
\text { Liquid expressed from boiled pureed soybeans } \\
\text { Roasted soybeans } \\
\text { Fried soybean curd patty with minced vegetables and seaweed } \\
\text { Dried soybean curd }\end{array}$ \\
\hline $\begin{array}{l}\text { Six other soy foods rec } \\
\text { Kinako } \\
\text { Soy sprouts } \\
\text { Soy burger } \\
\text { Soy strips } \\
\text { Tofu pie } \\
\text { Soy dog }\end{array}$ & $\begin{array}{l}\text { Roasted soybean flour } \\
\text { Sprouted soybeans } \\
\text { Burgers made with mashed soybeans and/or tofu } \\
\text { Film from soy milk } \\
\text { Dessert made with tofu } \\
\text { Hot dog usually made with soy protein isolate and tofu }\end{array}$ \\
\hline
\end{tabular}

controlled for differences in molecular weights and were presented in the unconjugated form. Soy-based foods also include another isoflavone, glycitein. Because the glycitein content was not available for several of the soy foods we examined, it was not included in our estimation of soy isoflavone intake. This was also consistent with other studies that have estimated dietary soy isoflavone intake in various populations $6,8,10,11,13$. Table 2 summarises the genistein and daidzein contents for each soy food used for this analysis.

Isoflavone values were available specifically for tofu, funyu, koyadofu, aburaage, okara, natto, soy nuts, miso, soybean condiment, soy milk, kinako, soy sprouts, tofu pie (tofu) and soy strips. For foods without published isoflavone contents, we used the isoflavone content of foods that were similar in protein content and were produced in a similar manner. For atsuage, we used the mean isoflavone values cited for aburaage and for tofumame, we used the mean isoflavone values cited for dry roasted soybeans. For ganmodoki, soy burger and soy dog, we used the median isoflavone values cited for soy hot dog and tempeh burger. For edamame we used the median isoflavone values cited for green soybeans.

\section{Otber data collected}

In addition to the NSFFQ, a brief risk factor questionnaire was administered and height and weight were measured using a standard clinic scale. Data from the baseline Kame examination also were available for this analysis. These data were collected $1-5$ years prior to the present study and included questions regarding demographics, acculturation, medications and supplements, lifestyle habits and diet. The dietary questionnaire used by the Kame
Project was designed specifically for Japanese Americans and asked participants about their usual intake of various Western and Asian foods during the past year (Hankin JH, Nomura AM, unpublished semi-quantitative food frequency questionnaire, 1991). Although Asian foods were included in this questionnaire, tofu was the only soybased food. Energy intake was estimated from this questionnaire (Hankin JH, Nomura AM, unpublished diet conversion program, 1991). In the tables presented in this paper we have indicated which data were from the baseline Kame Project examination.

\section{Statistical analyses}

Statistical analysis to examine characteristics associated with soy consumption

Correlation coefficients were estimated to compare the relation between dietary soy isoflavone intake and anthropometric covariates (weight and body mass index $\left(\mathrm{BMI} ; \mathrm{kg} \mathrm{m}^{-2}\right)$ ) and energy intake. These correlations were based on log-transformed values for dietary soy isoflavone intake, weight, BMI and energy intake.

Multiple regression and least-squares means general linear models were used to predict dietary soy isoflavone intake by categories of demographic, lifestyle and dietary covariates. Because dietary soy isoflavone intake was not normally distributed, values were log-transformed, which were then normally distributed. In least-squares means general linear models, the value obtained from the antilog of the logarithmic mean is the geometric mean, which more closely resembles the median. For covariates that were categorical, dummy variables were constructed for each category compared with the referent (lowest intake 
Table 2 Soy food and soy isoflavone intake in 274 older Japanese American women in King County, Washington State

\begin{tabular}{|c|c|c|c|c|c|c|c|c|c|c|}
\hline Soy food & $\begin{array}{l}\text { Number (\%) } \\
\text { who consumed } \\
\text { this food }^{\star}\end{array}$ & $\begin{array}{c}\text { Frequency/ } \\
\text { month } \\
\text { (mean } \pm \text { SD)† }\end{array}$ & $\begin{array}{c}\text { Frequency/ } \\
\text { month } \\
\text { (mean } \pm \text { SD) } \ddagger\end{array}$ & $\begin{array}{l}\text { Serving size }(\mathrm{g}) \\
(\text { mean } \pm \mathrm{SD}) \ddagger\end{array}$ & $\begin{array}{l}\text { Serving size } \\
\text { (approx. } \\
\text { equivalent) } \ddagger\end{array}$ & $\begin{array}{c}\text { Intake } \\
\left(\text { g day }^{-1}\right) \\
(\text { mean } \pm \text { SD }) \dagger\end{array}$ & $\begin{array}{l}\text { Genistein } \\
\left(\mu \mathrm{g} \mathrm{g}^{-1}\right. \\
\text { soy food }) \S\end{array}$ & $\begin{array}{l}\text { Daidzein } \\
\left(\mu \mathrm{g} \mathrm{g}^{-1}\right. \\
\text { soy food)§ }\end{array}$ & $\begin{array}{l}\text { Soy isoflavones } \\
\left(\mu \text { day }^{-1}\right) \\
(\text { mean } \pm \text { SD }) \dagger\end{array}$ & $\begin{array}{c}\text { Percentage of } \\
\text { total soy } \\
\text { isoflavone intake }\end{array}$ \\
\hline \multicolumn{11}{|c|}{ Soy foods included in the 14-item Nikkei Soy Food Frequency Questionnaire } \\
\hline Tofu & $274(100.0)$ & $4.7 \pm 5.2$ & $4.7 \pm 5.2$ & $119.5 \pm 60.4$ & (1/3 block) & $19.2 \pm 24.8$ & $166 \rrbracket$ & $76 \rrbracket$ & $4642.8 \pm 6010.8$ & 50.7 \\
\hline Miso: soup & $265(96.7)$ & $3.7 \pm 4.9$ & $3.8 \pm 4.9$ & $16.6 \pm 5.2$ & (1 T miso; 1 c soup) & $2.1 \pm 2.9$ & 246 & 161 & $839.5 \pm 1195.8$ & 10.9 \\
\hline Miso: marinades/dressing & 198 (72.3) & $1.6 \pm 2.9$ & $2.2 \pm 3.3$ & $36.7 \pm 49.9$ & $(21 / 2 \mathrm{~T})$ & $1.5 \pm 3.0$ & 246 & 161 & $629.7 \pm 1218.2$ & 7.7 \\
\hline Aburaage: strips & $160(58.4)$ & $1.1 \pm 2.2$ & $1.9 \pm 2.6$ & $7.9 \pm 6.0$ & (3/4 pouch) & $0.3 \pm 0.9$ & 280 & 178 & $154.0 \pm 409.0$ & 1.7 \\
\hline Aburaage: stuffed & 247 (90.1) & $0.8 \pm 1.2$ & $0.9 \pm 1.3$ & $13.8 \pm 7.8$ & (1 1/3 pouch) & $0.4 \pm 0.8$ & 280 & 178 & $179.0 \pm 373.7$ & 3.0 \\
\hline Tofumame & $51(18.6)$ & $0.7 \pm 4.2$ & $3.5 \pm 9.4$ & $101.7 \pm 82.6$ & $(1 / 2 c)$ & $0.7 \pm 3.2$ & 659 & 520 & $808.8 \pm 3782.8$ & 2.8 \\
\hline Natto & $75(27.4)$ & $0.7 \pm 2.9$ & $2.6 \pm 5.2$ & $51.6 \pm 33.0$ & (2/3 of 3 oz package) & $1.1 \pm 3.9$ & 290 & 219 & $560.0 \pm 1976.1$ & 3.4 \\
\hline Funyu & 83 (30.3) & $0.6 \pm 5.0$ & $1.9 \pm 8.9$ & $16.9 \pm 14.5$ & (1 cube) & $0.2 \pm 1.0$ & 164 & 143 & $51.2 \pm 304.3$ & 0.6 \\
\hline Soybean condiment & $33(12.0)$ & $0.3 \pm 1.3$ & $2.2 \pm 3.3$ & $24.5 \pm 28.6$ & $(11 / 2 \mathrm{~T})$ & $0.3 \pm 2.0$ & 152 & 150 & $79.6 \pm 594.4$ & 0.6 \\
\hline Edamame & $179(65.3)$ & $0.3 \pm 0.7$ & $0.5 \pm 0.9$ & $85.8 \pm 75.6$ & $(3 / 4 \mathrm{c})$ & $1.1 \pm 3.0$ & 729ף & $546 \pi$ & $1395.4 \pm 3829.8$ & 12.2 \\
\hline Atsuage: strips & $94(34.3)$ & $0.2 \pm 0.5$ & $0.5 \pm 0.8$ & $75.5 \pm 41.7$ & (1/2 block) & $0.5 \pm 1.8$ & 280 & 178 & $242.9 \pm 842.9$ & 2.2 \\
\hline Atsuage: stuffed & $3(1.1)$ & $0.0 \pm 0.0$ & $0.3 \pm 0.1$ & $94.7 \pm 41.0$ & (2/3 block) & $0.0 \pm 0.1$ & 280 & 178 & $3.9 \pm 40.2$ & 0.1 \\
\hline Okara & $141(51.5)$ & $0.2 \pm 0.4$ & $0.3 \pm 0.5$ & $114.2 \pm 61.7$ & $(1 / 2 c)$ & $0.7 \pm 2.1$ & 65 & 54 & $86.3 \pm 247.9$ & 1.2 \\
\hline Soy milk & $7(2.6)$ & $0.1 \pm 1.8$ & $5.1 \pm 11.2$ & $359.6 \pm 285.4$ & $(11 / 2 c)$ & $0.9 \pm 11.4$ & 61 & 45 & $90.3 \pm 1212.4$ & 0.3 \\
\hline Soy nuts & $22(8.0)$ & $0.1 \pm 0.6$ & $1.0 \pm 2.0$ & $47.6 \pm 40.9$ & $(1 / 2 c)$ & $0.2 \pm 1.5$ & 659 & 520 & $190.2 \pm 1815.1$ & 0.7 \\
\hline Ganmodoki & $56(20.4)$ & $0.1 \pm 0.3$ & $0.4 \pm 0.6$ & $51.7 \pm 35.3$ & (1 patty) & $0.2 \pm 0.8$ & 139ף & $49 \rrbracket$ & $31.6 \pm 153.0$ & 0.3 \\
\hline Koyadofu & $83(30.3)$ & $0.1 \pm 0.3$ & $0.3 \pm 0.4$ & $18.5 \pm 15.6$ & (1 block) & $0.1 \pm 0.2$ & 422 & 253 & $36.3 \pm 138.2$ & 0.4 \\
\hline \multicolumn{11}{|l|}{ Six other soy foods recalled } \\
\hline Kinako & $10(3.6)$ & $0.1 \pm 1.8$ & $3.5 \pm 9.5$ & $22.4 \pm 19.8$ & (2 T) & $0.0 \pm 0.6$ & 988 & 993 & $92.2 \pm 1205.1$ & 0.3 \\
\hline Soy sprouts & $6(2.2)$ & $0.0 \pm 0.3$ & $1.6 \pm 1.3$ & $53.1 \pm 43.7$ & $(1 \mathrm{c})$ & $0.1 \pm 0.9$ & 216 & 191 & $38.1 \pm 374.8$ & 0.5 \\
\hline Soy burger & $12(4.4)$ & $0.0 \pm 0.4$ & $0.9 \pm 1.6$ & $134.3 \pm 95.3$ & (1 1/4 patties) & $0.1 \pm 1.3$ & $139 \pi$ & 49ף & $27.9 \pm 242.3$ & 0.3 \\
\hline Soy strips & $1(0.4)$ & $0.0 \pm 0.0$ & 0.5 & 150.0 & (2 c) & $0.0 \pm 0.1$ & 325 & 182 & $4.6 \pm 75.6$ & 0.0 \\
\hline Tofu pie & $4(1.5)$ & $0.0 \pm 0.1$ & $0.4 \pm 0.6$ & $43.0 \pm 0.0$ & (1 slice; $1 / 8$ block tofu) & $0.0 \pm 0.1$ & $166 \rrbracket$ & $76 \pi$ & $2.1 \pm 27.9$ & 0.0 \\
\hline Soy dog & $1(0.4)$ & $0.0 \pm 0.0$ & 0.1 & 38.0 & (1 dog) & $0.0 \pm 0.0$ & 139ף & 49ף & $0.1 \pm 1.2$ & 0.0 \\
\hline
\end{tabular}

* Consumed at least once in the past year.

$\dagger$ Among sample of 274 women.

$\ddagger$ Among consumers only.

$\S$ From USDA-lowa State database ${ }^{15}$, unless otherwise stated.

I From Reinli and Block ${ }^{16}$

$T=$ tablespoon; $c=$ cup 
for dietary variables). $P$-values were based on multiple regression models.

Reproducibility (test-retest reliability) of the Nikkei Soy Food Frequency Questionnaire

To determine its test-retest reliability ${ }^{17}$, administration of the NSFFQ was repeated 1 to 4 months after the initial NSFFQ in 13 women who were randomly selected using a random digit table. The means of the initial and repeated measurements of daily soy isoflavone intake were estimated, as was the standard error (SE) of the differences (standard deviation (SD) of the mean difference between measurements, divided by the square root of the sample size) and the intraclass correlation coefficient. Because dietary soy isoflavone intake was not normally distributed, the intraclass correlation coefficient was based on log-transformed values. We also compared the frequency of tofu consumption measured by the NSFFQ with the frequency of tofu consumption measured by the Kame Project's dietary questionnaire, measured 1-5 years prior to the present study. Because frequency was categorised in the Kame Project's dietary questionnaire, data obtained by the NSFFQ were categorised accordingly for the purpose of this analysis. The weighted kappa statistic was estimated to describe the agreement between the two measures ${ }^{17}$.

All statistical analyses were conducted using Statistical
Analysis System software (release 6.12, SAS Institute, Inc., Cary, NC).

\section{Results}

\section{Study population}

Two-hundred-and-seventy-four Japanese American women aged 65 to 93 years (mean 72.8, SD 5.1) completed the NSFFQ between October 1995 and May 1997. The majority of women $(82.8 \%)$ were born in the continental United States, $1.5 \%$ were born in Hawaii, $14.2 \%$ were born in Japan, and 1.5\% were born elsewhere (China, North Korea or Peru). Almost all of the parents of these women were born in Japan, except for seven mothers and two fathers who were born in the United States. All women were of 100\% Japanese ethnicity. Women participating in the present study were more likely to be born in the US than the population from which they were recruited, and therefore were more representative of older US-born Japanese American women living in King County.

\section{Commonly consumed soy foods}

The frequency of consumption and serving sizes of the 14 soy foods included in the NSFFQ and the additional six soy foods recalled are summarised in Table 2. Tofu was consumed by all of the women in this study. Miso and

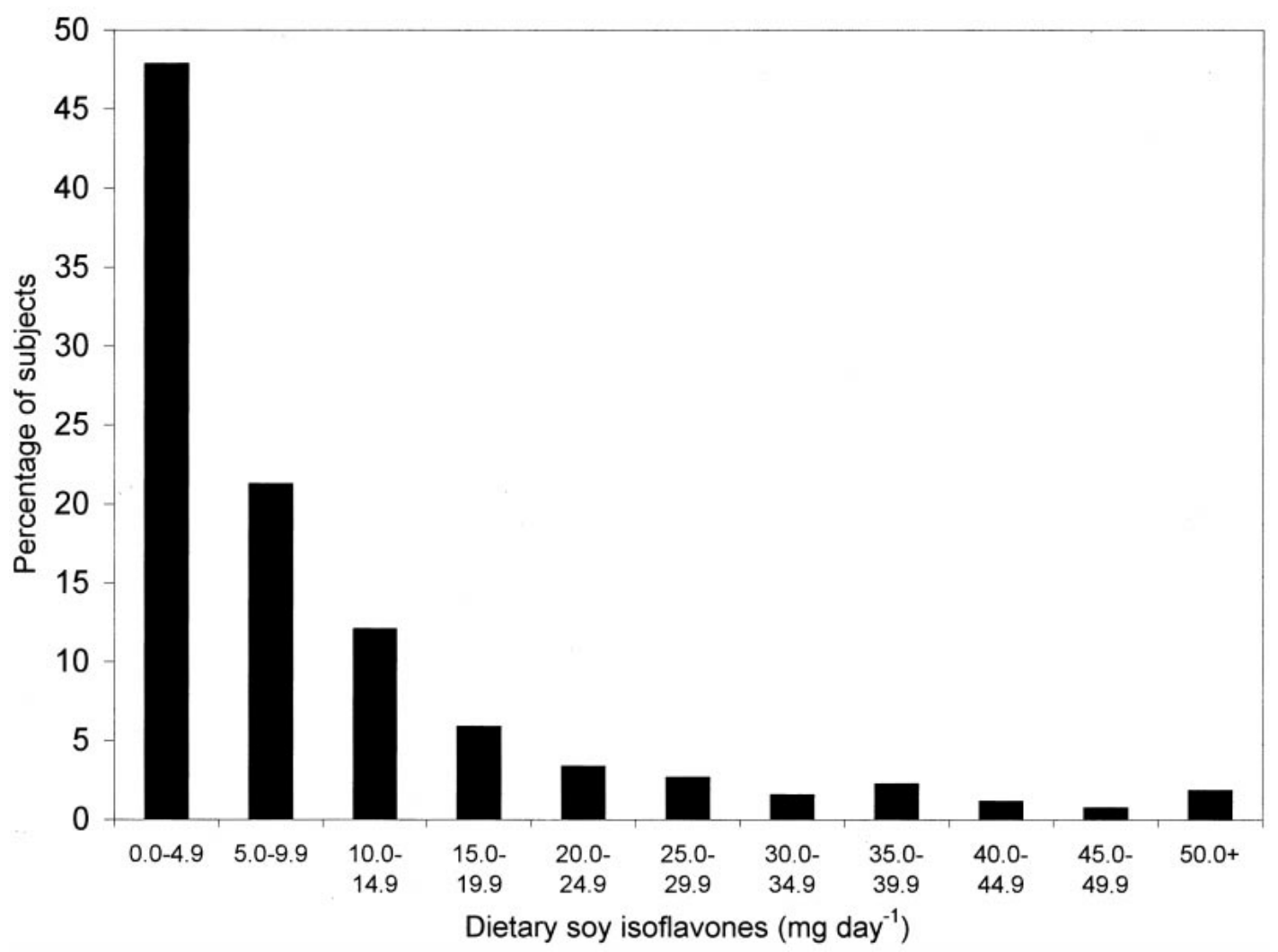

Fig. 1 Percentage of subjects by dietary soy isoflavone intake (genistein plus daidzein) in 274 older Japanese American women in King County, Washington State 
aburaage were consumed by over $90 \%$ of the women, whereas soy nuts and soy milk were consumed by less than $10 \%$. Table 2 also summarises the mean daily intake of each soy food.

\section{Dietary soy isoflavone intake}

The mean dietary soy isoflavone intake was 10.2 (SD, 12.4) $\mathrm{mg} \mathrm{day}^{-1}$ (range $=0.5-83.6$ ). This represented a combined intake of $6.4(\mathrm{SD}, 7.6) \mathrm{mg} \mathrm{day}^{-1}$ of genistein and $3.8(\mathrm{SD}, 4.8) \mathrm{mg} \mathrm{day}^{-1}$ of daidzein. Figure 1 shows the distribution of dietary soy isoflavone intake. The 25 th, 50 th and 75 th percentiles of dietary soy isoflavone intake in $\mathrm{mg} \mathrm{day}^{-1}$ were 2.9, 5.3 and 12.5 , respectively. The majority of dietary soy isoflavones was derived from nonfermented soy foods (mean, 8.0; SD, 10.7), rather than from fermented soy foods (mean, 2.2; SD, 3.2). The soy food contributing most to total dietary soy isoflavone intake was tofu $(50.7 \%$, range $=0.4-100.0)$. Other soy foods contributing at least $5 \%$ to the total of dietary soy isoflavone intake were miso and edamame (Table 2).

\section{Characteristics associated with soy consumption}

Dietary soy isoflavone intake was correlated weakly, although statistically significantly, with energy intake ( $r=0.23, P<0.001)$, but not with body size $(r=-0.02$, $P=0.7$ for weight; $r=-0.02, P=0.7$ for BMI).

The strongest predictor of dietary soy isoflavone intake was language spoken at the interview. Among women who spoke English at the interview, the mean dietary soy isoflavone intake was $7.8(\mathrm{SD}, 8.9) \mathrm{mg} \mathrm{day}^{-1}$ and among women who spoke Japanese it was 23.1 (SD, 19.5) $\mathrm{mg}$ day $^{-1}$. The median intakes for English and Japanese speakers were 4.5 and $18.1 \mathrm{mg} \mathrm{day}^{-1}$, respectively. Place of birth also was a strong predictor of dietary soy isoflavone intake. Women born in the continental United States consumed 7.8 (SD, 8.6) $\mathrm{mg} \mathrm{day}^{-1}$, women born in Hawaii consumed 6.0 (SD, 4.4) $\mathrm{mg} \mathrm{day}^{-1}$, women born in Japan consumed 22.5 (SD, 20.7) $\mathrm{mg} \mathrm{day}^{-1}$, and women born elsewhere consumed 27.5 (SD, 10.7) $\mathrm{mg} \mathrm{day}^{-1}$. The median intakes for these groups were 4.5, 3.6, 15.0 and $21.6 \mathrm{mg} \mathrm{day}{ }^{-1}$, respectively. Place of birth was not a significant predictor of dietary soy isoflavone intake after adjusting for language spoken at the interview and energy intake $(P=0.2)$. Language remained a significant predictor after adjusting for place of birth and energy intake $(P<0.001)$.

Table 3 summarises the geometric mean adjusted dietary soy isoflavone intake by categories of covariates found to be significant predictors of dietary soy isoflavone intake. Adjustments were made to determine predictors of dietary soy isoflavone intake, independent of language and energy intake. As expected, dietary soy isoflavone intake was positively associated with the consumption of tofu, measured by the Kame dietary questionnaire 1-5 years prior to the present study. Dietary soy isoflavone intake was positively associated with the consumption of

Table 3 Adjusted* geometric mean (standard error; SE) dietary soy isoflavone intake (genistein plus daidzein; $\mathrm{mg} \mathrm{day}^{-1}$ ) by categories of significant dietary and lifestyle covariates, in 274 older Japanese American women in King County, Washington State

\begin{tabular}{|c|c|c|c|c|c|}
\hline & & $N$ & $\begin{array}{l}\text { Geometric } \\
\text { mean (SE) }\end{array}$ & $P$-value $†$ & $P$ for trend \\
\hline \multirow[t]{3}{*}{ Tofu (frequency of intake) $\ddagger$} & $<1 /$ week (referent) & 128 & $3.8(1.1)$ & & \\
\hline & $1-2 /$ week & 83 & $6.9(1.1)$ & 0.0001 & \\
\hline & 3-6/week & 48 & $12.9(1.1)$ & 0.0001 & 0.0001 \\
\hline \multirow{3}{*}{$\begin{array}{l}\text { Kamaboko (steamed fish cakes; } \\
\text { frequency of intake) } \ddagger\end{array}$} & $<1 /$ month (referent) & 113 & $4.7(1.1)$ & & \\
\hline & $1-3 /$ month & 119 & $6.2(1.1)$ & 0.04 & \\
\hline & 1-2/week & 29 & $8.4(1.2)$ & 0.009 & 0.004 \\
\hline \multirow{7}{*}{$\begin{array}{l}\text { Manju (azuki or lima-bean-filled pastry) or mochi } \\
\text { (sweet rice) (frequency of intake) } \ddagger \\
\text { Low-fat or non-fat milk (frequency of intake) } \ddagger\end{array}$} & $<1 /$ month (referent) & 137 & $4.9(1.1)$ & & \\
\hline & 1/month-2/week & 122 & $6.7(1.1)$ & 0.01 & \\
\hline & $<1 /$ month (referent) & 92 & $4.6(1.1)$ & & \\
\hline & $1-3 /$ month & 30 & $5.8(1.2)$ & 0.3 & \\
\hline & $1-2 /$ week & 39 & $6.4(1.2)$ & 0.1 & \\
\hline & 3-6/week & 38 & $6.0(1.2)$ & 0.2 & \\
\hline & $1+/$ day & 62 & $6.7(1.1)$ & 0.03 & 0.03 \\
\hline \multirow[t]{3}{*}{ Yellow or red vegetables (frequency of intake) $\ddagger$} & $1 /$ month-2/week (referent) & 93 & $4.7(1.1)$ & & \\
\hline & $3-4 /$ week & 71 & $5.0(1.1)$ & 0.7 & \\
\hline & 5/week-1/day & 96 & $7.4(1.1)$ & 0.003 & 0.003 \\
\hline \multirow[t]{3}{*}{ Butter (frequency of intake) $\ddagger$} & $<1 /$ month (referent) & 190 & $6.1(1.1)$ & & \\
\hline & $1-3 /$ month & 26 & $6.2(1.2)$ & 0.9 & \\
\hline & 1-4/week & 43 & $3.9(1.2)$ & 0.01 & 0.01 \\
\hline \multirow[t]{4}{*}{ Number of blocks walked each day $\ddagger$} & 0 (referent) & 69 & $4.3(1.1)$ & & \\
\hline & $1-10$ & 80 & $6.5(1.1)$ & 0.008 & \\
\hline & $11-20$ & 53 & $5.7(1.1)$ & 0.10 & \\
\hline & $21+$ & 48 & $7.2(1.1)$ & 0.004 & 0.01 \\
\hline \multirow[t]{2}{*}{ Vitamin E supplement use } & Not current (referent) & 175 & $5.1(1.1)$ & & \\
\hline & Current & 99 & $6.6(1.1)$ & 0.04 & \\
\hline
\end{tabular}

* Adjusted for language spoken at the interview and energy intake.

† Compared with the referent group.

$\ddagger$ Data are from the baseline examination of the Kame Project. 
kamaboko (steamed fish cakes; a traditional Japanese dish), manju (azuki or lima-bean-filled pastry) or mochi (sweet rice) (both traditional Japanese desserts), low-fat or non-fat milk, and yellow or red vegetables. Dietary soy isoflavone intake was negatively associated with the consumption of butter. Women consuming kamaboko at least once per week consumed almost twice as much dietary soy isoflavones as women who consumed kamaboko less than once per month. Women in the highest category of low-fat/non-fat milk or yellow/red vegetables consumed approximately 1.5 times more dietary soy isoflavones than women consuming these foods less frequently. Women consuming manju or mochi at least once per month consumed approximately 1.4 times more dietary soy isoflavones than women consuming these foods less than once per month. Women consuming butter almost daily consumed almost half as much dietary soy isoflavones as women consuming butter less than once per month. Foods not associated with the intake of dietary soy isoflavones included meat (beef, pork or poultry), green vegetables, fruit, bread and cake (data not shown). Dietary soy isoflavone intake was almost twice as high in women walking 21 or more blocks each day (approximately two miles) than in women who walked 0 blocks per day. Current vitamin E supplement users consumed about 1.3 times more dietary soy isoflavones than women who were not current vitamin E users. Age, education, income, smoking, alcohol use and postmenopausal oestrogen use were not associated with dietary soy isoflavone intake (data not shown).

\section{Comparison with other studies in Japanese or American samples}

Table 4 compares the estimated soy intake from our study sample with estimates from other Japanese and American samples. The estimated mean dietary intake of soy isoflavones in our sample was twice that of Caucasian women living in $\mathrm{Hawaii}^{7}$ and a quarter to a half that of Japanese women living in Hawaii or Japan ${ }^{6-8,13}$. The highest intake observed in our sample (83.6 $\mathrm{mg} \mathrm{day}^{-1}$ ) was similar to the highest intake observed in Japanese women living in Japan $\left(87.7 \mathrm{mg} \mathrm{day}^{-1}\right)^{8}$. The median intake of soy isoflavones estimated from 1-day and 16-day food records in a sample of Japanese men and women living in Japan was four to six times higher ${ }^{11}$, respectively, than the median intake in our sample. The mean daily intake of dietary soy isoflavones in the Japanese speakers of our sample was roughly the same as in two Japanese samples from Hawaii and Japan ${ }^{6,7}$. In contrast, the Japanese samples from the Iwate prefecture in the Tohoku region of Japan consumed considerably higher amounts of soy isoflavones ${ }^{8,13}$. The authors commented that the per capita consumption of pulses (primarily soybean products) in the Tohoku region of Japan is 33\% higher than the national average ${ }^{13}$. Among the English speakers in our sample, their consumption of tofu was about the same as in other Japanese samples ${ }^{6,18}$, whereas the consumption of other soy foods was considerably less. The intake of dietary soy isoflavones in our sample was similar to the intake in a sample of predominantly Caucasian American faculty, staff and students at a Seattle suburb naturopathic university (a sample of persons likely to consume soy foods $)^{10}$. The methods used for determining soy intake in the various samples compared here are summarised in Table 4.

The most commonly consumed soy foods in our sample - tofu, miso and aburaage - were also the most commonly consumed soy foods in a Japanese sample of men and women living in Nagoya, Japan ${ }^{11}$. In contrast, the types of soy foods regularly consumed by our sample differed considerably from that of the other Seattle area sample ${ }^{10}$. Both samples regularly consumed tofu and miso. However, the naturopathic university sample also consumed soy foods not consumed by our sample: tempeh (fermented soybean cakes, an Indonesian staple) and westernised foods (soy yoghurt and soy cheese).

\section{Reproducibility (test-retest reliability) of the Nikkei Soy Food Frequency Questionnaire}

The 13 women participating in the reproducibility study were more likely to be Japanese speakers, compared with the 274 women from which they were sampled (38.5 vs. 15.6\%). They also were higher soy isoflavone consumers. The initial and repeated measurements were separated by 1 to 4 months (mean, 1.8; SD, 0.9). The means of the initial and repeated measurements of daily soy isoflavone intake were 13.7 (SD, 17.5) and 14.0 (SD, 15.0) $\mathrm{mg} \mathrm{day}^{-1}$, respectively. The standard error (SE) of the differences was 2.0. The intraclass correlation coefficient was good $(r=0.72)$. The mean differences were negligible, suggesting good agreement between the two measurements, on average. The SE of the differences was small, suggesting that the two measurements had good agreement for individuals and that there was no systematic difference between the two measurements.

Two-hundred-and-thirty-nine women completed the Kame Project's dietary questionnaire $1-5$ years (mean, 3.0; SD, 0.7) prior to completing the NSFFQ. The weighted kappa statistic comparing the frequency of tofu consumption from the two dietary measures was 0.44 , which suggests moderate agreement. The majority of women $(55 \%)$ reported the same tofu frequency. An additional $38 \%$ of the women reported similar frequency (a one-category difference). Six per cent of the women reported inconsistent tofu frequency, which may reflect individual errors in recall or a change in diet.

\section{Discussion}

We estimated dietary soy isoflavone intake in a sample of 274 older Japanese American women living in the Seattle area of Washington State, using the 14-item Nikkei Soy 
Table 4 Soy consumption in American and Japanese sampled populations

\begin{tabular}{|c|c|c|c|c|c|c|c|c|c|c|c|}
\hline Reference & Study site & Description of sample & $\begin{array}{l}\text { Sample } \\
\text { size }\end{array}$ & $\begin{array}{l}\text { Dietary instrument } \\
\text { used }^{*}\end{array}$ & $\begin{array}{l}\text { Tofu (mean) } \\
\left(\mathrm{g} \mathrm{day}^{-1}\right)\end{array}$ & $\begin{array}{c}\text { Miso } \\
(\text { mean })^{-1} \\
\left(\mathrm{~g} \mathrm{day}^{-1}\right)\end{array}$ & $\begin{array}{c}\text { Aburaage } \\
\text { (mean) } \\
\left(\text { g day }^{-1}\right)\end{array}$ & $\begin{array}{c}\text { Natto } \\
(\text { mean) } \\
\left(\text { g day }^{-1}\right)\end{array}$ & $\begin{array}{l}\text { Edamame } \\
(\text { mean }) \\
\left(\text { g day }^{-1}\right)\end{array}$ & $\begin{array}{c}\text { Isoflavones† } \\
\text { (mean) } \\
\left.\text { (mg day }^{-1}\right)\end{array}$ & $\begin{array}{l}\text { Isoflavones† } \\
\text { (median) } \\
\left.\text { (mg day }^{-1}\right)\end{array}$ \\
\hline Kirk et al., $1999^{10}$ & $\begin{array}{l}\text { Bellevue, WA, } \\
\text { USA }\end{array}$ & $\begin{array}{l}\text { Caucasian men and } \\
\text { women } \neq\end{array}$ & 51 & $\begin{array}{l}\text { FFQ; } 40 \text { soy foods; } \\
\text { past year }\end{array}$ & & & & & & 11.0 & \\
\hline \multirow[t]{4}{*}{$\begin{array}{l}\text { Maskarinec et al., } \\
1998^{7}\end{array}$} & \multirow[t]{4}{*}{$\begin{array}{l}\text { Honolulu, HI, } \\
\text { USA }\end{array}$} & Caucasian women & 42 & $\begin{array}{l}\text { FFQ; } 12 \text { soy foods; } \\
\text { past year }\end{array}$ & & & & & & 5.2 & \\
\hline & & Caucasian women & 42 & $\begin{array}{l}\text { FFQ; } 12 \text { soy foods; } \\
\text { past } 24 \text { hours }\end{array}$ & & & & & & 6.9 & \\
\hline & & $\begin{array}{l}\text { Japanese American } \\
\text { women }\end{array}$ & 25 & $\begin{array}{l}\text { FFQ; } 12 \text { soy foods; } \\
\text { past year }\end{array}$ & & & & & & 18.9 & \\
\hline & & $\begin{array}{l}\text { Japanese American } \\
\text { women }\end{array}$ & 25 & $\begin{array}{l}\text { FFQ; } 12 \text { soy foods; } \\
\text { past } 24 \text { hours }\end{array}$ & & & & & & 31.3 & \\
\hline \multirow[t]{4}{*}{ Present study } & \multirow[t]{4}{*}{$\begin{array}{l}\text { Seattle, WA, } \\
\text { USA }\end{array}$} & $\begin{array}{l}\text { Japanese American } \\
\text { women }\end{array}$ & & & & & & & & & \\
\hline & & $\begin{array}{l}\text { English and Japanese } \\
\text { speakers }\end{array}$ & 274 & $\begin{array}{l}\text { FFQ; } 14 \text { soy foods; } \\
\text { past year }\end{array}$ & 19.2 & 3.6 & 0.7 & 1.1 & 1.1 & 10.2 & 5.3 \\
\hline & & English speakers only & 232 & $\begin{array}{l}\text { FFQ; } 14 \text { soy foods; } \\
\text { past year }\end{array}$ & 17.5 & 3.1 & 0.5 & 0.3 & 0.7 & 7.8 & 4.5 \\
\hline & & $\begin{array}{l}\text { Japanese speakers } \\
\text { only }\end{array}$ & 42 & $\begin{array}{l}\text { FFQ; } 14 \text { soy foods; } \\
\text { past year }\end{array}$ & 28.3 & 6.4 & 1.9 & 5.4 & 3.1 & 23.1 & 18.1 \\
\hline Nagata et al., $1997^{6}$ & Gifu, Japan & Japanese women & 50 & $\begin{array}{l}\text { FFQ; } 9 \text { soy foods; } \\
\text { past year }\end{array}$ & 15.9 & 7.7 & 4.0 & 4.3 & 4.1 & 20.6 & \\
\hline \multirow{2}{*}{$\begin{array}{l}\text { Adlercreutz et al., } \\
1991^{18}\end{array}$} & \multirow[t]{2}{*}{ Kyoto, Japan } & Japanese women & 10 & 3-day diet record & 25.0 & 12.5 & 2.6 & 2.4 & 7.7 & & \\
\hline & & Japanese men & 9 & 3-day diet record & 18.7 & 8.5 & 3.7 & 0.9 & 6.5 & & \\
\hline Kimira et al., $1998^{8}$ & Iwate, Japan & Japanese women & 50 & 3-day diet record & & & & & & 39.5 & \\
\hline Arai et al., $2000^{13}$ & Iwate, Japan & Japanese women & 106 & 3-day diet record & 48.6 & 17.0 & 3.9 & 14.8 & 3.8 & 46.5 & \\
\hline \multirow[t]{2}{*}{ Wakai et al., $1999^{11}$} & \multirow[t]{2}{*}{ Nagoya, Japan } & $\begin{array}{l}\text { Japanese men and } \\
\text { women }\end{array}$ & 1232 & 1-day diet record & & & & & & & 31.7 \\
\hline & & $\begin{array}{l}\text { Japanese men and } \\
\text { women }\end{array}$ & 88 & $\begin{array}{l}\text { Four 4-day diet records } \\
\text { (16 days) }\end{array}$ & & & & & & & 24.4 \\
\hline
\end{tabular}

\section{${ }^{*} \mathrm{FFQ}=$ food-frequency questionnaire.}

† Genistein plus daidzein for all studies, except not specified for Maskarinec et al., $1998^{7}$. The sources for the isoflavone data were:

- Kirk et al., 1999 10 - Reinli and Block' ${ }^{10}$, Wang and Murphy (J. Agric. Food. Chem. 1994; 42: 1666-73), Coward et al. (J. Agric. Food Chem. 1993; 41: 1961-7);

- Maskarinec et al., 1998 - Franke et al. (Proc. Am. Assoc. Cancer Res. 1997; 38: 112 [abstract]);

- Nagata et al., $1997^{6}$ - Coward et al. (J. Agric. Food Chem. 1993; 41: 1961-7), Fukutake (Food Chem. Toxicol. 1996; 34: 457-61);

Adlercreutz et al., $1991^{1}$ - did not estimate isoflavone intake

- Arai et al. $2000^{13}$ - Kimira et al., 1998.

- Wakai et al., 199911 - several sources were used, including Reinli and Block ${ }^{16}$, Wang and Murphy (J. Agric. Food Chem. 1994; 42: 1674-7), Fukutake (Food Chem. Toxicol. 1996; 34: 457-61), Franke et al. (Proc.

Soc Exp. Biol Med 1998. 217: 263-73).

\# This was a predominantly Caucasian sample of faculty, staff and students at a Seattle suburb naturopathic university who were likely to consume soy foods. 
Food Frequency Questionnaire. Responses were converted to quantitative estimates of soy isoflavones (genistein plus daidzein). The mean intake of dietary soy isoflavones in this sample was intermediate between published estimates in Caucasians living in Hawaii ${ }^{7}$ and Japanese living in $\operatorname{Japan}^{6,8,13}$. The types of soy foods consumed by this sample were similar to those consumed by other Japanese samples ${ }^{11}$ but differed, however, from those of a predominately Caucasian sample of faculty, staff and students at a Seattle suburb naturopathic university who also consumed westernised soy foods ${ }^{10}$. Dietary soy isoflavone intake was positively associated with healthy lifestyle and dietary habits.

An important limitation to our study is that we do not present data on the validity of the NSFFQ. This is due in part because we felt that no gold standard existed against which to validate our estimate of regular soy isoflavone intake. Other measures, such as 24-hour recalls, 1-week food records or 24-hour urine or plasma samples, would likely have reflected short-term intake, rather than usual intake. Because of the relative infrequency of soy intake in our sample, a short-term measurement would likely have resulted in greater error in the measurement of usual soy isoflavone exposure, compared with our measurement of intake over the past year. For example, a previous study found that urinary isoflavone excretion estimated from overnight urine samples was strongly correlated with dietary soy isoflavone intake during the previous 24hour period $(r=0.62 ; P<0.001)$, but less strongly correlated to intake during the previous year $(r=0.31$; $P<0.01)^{7}$. A study that compared longer-term dietary soy isoflavone intake (in the previous 5-year period) observed a correlation of $0.54(P<0.001)$ between dietary intake and urinary excretion of soy isoflavones ${ }^{12}$. Another study compared fasting plasma and 24-hour urinary concentrations of isoflavones with dietary intake estimated from a 3-day food record, and found correlations in the range of $0.34-0.43^{13}$.

Several steps were taken to minimise measurement error in our study. The NSFFQ was designed to measure the current and usual intake of soy foods. Therefore, the NSFFQ queried about soy foods consumed during the past year. Soy intake was based on a comprehensive measurement of soy foods regularly consumed by women in this population. Photographs and descriptions of each soy food queried were used to aid in the recall of these foods. A bilingual Japanese American interviewer was employed who was able to accurately communicate the diet information.

The data presented here suggest that Japanese Americans may consume soy isoflavones at amounts of a quarter to a half that of their Japanese counterparts. The data also suggest potential confounders of the relation between dietary soy isoflavone intake and health outcomes. Although many of these factors may be specific to this sample, these data suggest that diet and exercise may be associated with soy intake, and should be considered in future studies of soy intake and health outcomes.

\section{Acknowledgements}

This work was supported by grant number AG09769, and a graduate research supplement from the National Institute on Aging.

This paper was presented in part at the annual meeting of the North American Menopause Society, New York, NY, 23-25 September 1999 and at the 3rd International Symposium on the Role of Soy in Preventing and Treating Chronic Disease, Washington, DC, 31 October-3 November 1999 .

The authors thank the faculty and staff of the University of Washington's Kame Project and Nikkei Long Term Care Project for their support and assistance. The authors thank focus group discussants, Patti Tsubota Boorkman, Nina Chinn, Greta Hoshibata, Mitzi Sakaguchi, Masako Tomita, Linda Yamaguchi Zee and Nancy Zee, for their contributions in the design of the Nikkei Soy Food Frequency Questionnaire. The authors thank Yuriko Courtney and Masaru Aoyama for translating the Nikkei Soy Food Frequency Questionnaire and Patti Tsubota Boorkman for her assistance in photographing the soy foods. The authors thank Dr Laura Gibbons for her assistance in database management and statistical program writing. The authors thank Drs Alan Kristal and Ruth Patterson for their helpful comments regarding the statistical analysis and interpretation of the reproducibility study of the Nikkei Soy Food Frequency Questionnaire. The authors thank two anonymous reviewers for their constructive comments on an earlier version of this paper. Lastly, the authors gratefully acknowledge the contributions of the Japanese American community of King County, Washington State.

\section{References}

1 Miksicek RJ. Interaction of naturally occurring nonsteroidal estrogens with expressed recombinant human estrogen receptor. J. Steroid Biochem. Mol. Biol. 1994; 49: 153-60.

2 Miksicek RJ. Estrogenic flavonoids: structural requirements for biological activity. PSEBM 1995; 208: 44-50.

3 Setchell KD, Borriello SP, Hulme P, Kirk DN, Axelson M. Nonsteroidal estrogens of dietary origin: possible roles in hormone-dependent disease. Am. J. Clin. Nutr. 1984; 40: 569-78.

4 Adlercreutz H. Western diet and Western diseases: some hormonal and biochemical mechanisms and associations. Scand. J. Clin. Lab. Invest. Suppl. 1990; 201: 3-23.

5 Adlercreutz H, Hamalainen E, Gorbach S, Goldin B. Dietary phyto-oestrogens and the menopause in Japan. Lancet 1992; 339: 1233.

6 Nagata C, Kabuto M, Kurisu Y, Shimizu H. Decreased serum estradiol concentration associated with high dietary intake of soy products in premenopausal Japanese women. Nutr. Cancer 1997; 29: 228-33.

7 Maskarinec G, Singh S, Meng L, Franke AA. Dietary soy intake and urinary isoflavone excretion among women 
from a multiethnic population. Cancer Epidemiol. Biomark. Prev. 1998; 7: 613-9.

8 Kimira M, Arai Y, Shimoi K, Watanabe S. Japanese intake of flavonoids and isoflavonoids from foods. J. Epidemiol. 1998; 8: $168-75$.

9 Seow A, Shi C-Y, Franke AA, Hankin JH, Lee H-P, Yu MC. Isoflavonoid levels in spot urine are associated with frequency of dietary soy intake in a population-based sample of middle-aged and older Chinese in Singapore. Cancer Epidemiol. Biomark. Prev. 1998; 7: 135-40.

10 Kirk P, Patterson RE, Lampe J. Development of a soy food frequency questionnaire to estimate isoflavone consumption in US adults. J. Am. Diet. Assoc. 1999; 99: 558-63.

11 Wakai K, Egami I, Kato K, et al. Dietary intake and sources of isoflavones among Japanese. Nutr. Cancer 1999; 33: 139-45.

12 Chen Z, Zheng W, Custer LJ, et al. Usual dietary consumption of soy foods and its correlation with the excretion rate of isoflavonoids in overnight urine samples among Chinese women in Shanghai. Nutr. Cancer 1999; 33: 82-7.

13 Arai Y, Uehara M, Sato Y, et al. Comparison of isoflavones among dietary intake, plasma concentration and urinary excretion for accurate estimation of phytoestrogen intake. $J$. Epidemiol. 2000; 10: 127-35.

14 Graves $\mathrm{AB}$, Larson EB, Edland SD, et al. Prevalence of dementia and its subtypes in the Japanese American population of King County, Washington State. The Kame Project. Am.J. Epidemiol. 1996; 144: 760-71.

15 United States Department of Agriculture. USDA-Iowa State University Database on the Isoflavone Content of Foods, Release 1.1 - 1999 [Online]. Available at http://www.nal. usda.gov/fnic/foodcomp/Data/isoflav/isoflav.html.

16 Reinli K, Block G. Phytoestrogen content of foods - a compendium of literature values. Nutr. Cancer 1996; 26: $123-48$.

17 Armstrong BK, White E, Saracci R. Principles of Exposure Measurement in Epidemiology. New York: Oxford University Press, 1992.

18 Adlercreutz H, Honjo H, Higashi A, et al. Urinary excretion of lignans and isoflavonoid phytoestrogens in Japanese men and women consuming a traditional Japanese diet. Am. J. Clin. Nutr. 1991; 54: 1093-100. 